\title{
Społeczne wzory konsumpcji a orientacje aksjologiczne pracowników wrocławskiego sektora kultury i produkcji gier wideo w świetle badań własnych
}

DOI: 10.19195/2083-7763.9.4

\section{Wprowadzenie}

Tematyka dotycząca sfery wartości oraz hierarchii wartości panującej w grupach społecznych jest obecna w empirycznej i teoretycznej refleksji socjologicznej od momentu powstania socjologii jako dyscypliny naukowej. Również współcześnie badania nad systemami aksjologicznymi, ich relacjami ze strukturą społeczną oraz determinantami ich konstrukcji są prowadzone nieustannie przez badaczy społecznych. Jednak wartości (oraz sam ich system) jako kategoria analityczna są obarczone krytyką ze strony środowiska naukowego, mimo swojej niezaprzeczalnej użyteczności i - w sporej mierze - empirycznej skuteczności. Earl Babbie uważa, że pojęcie wartości jest konstruktem metodologicznym, ponieważ praktycznie niewykonalnym zadaniem jest udowodnienie ich istnienia w rzeczywistości społecznej ${ }^{1}$.

Pomimo toczącej się dyskusji dotyczącej skuteczności analitycznej owej kategorii badawczej celem artykułu jest analiza relacji łączących usytuowanie strukturalne badanych z preferowanymi przez nich wartościami oraz ze społecznymi wzorami ${ }^{2}$ konsumpcji oferty miejskiej. Materiałem badawczym są dane uzyskane

${ }^{1}$ E. Babbie, Podstawy badań społecznych, przeł. W. Betkiewicz et al., Warszawa 2008, s. $145-146$.

${ }^{2}$ Zdaniem T. Szczurkiewicza (Studia socjologiczne, Warszawa 1970) grupa społeczna nie może istnieć bez wzorów społecznego działania, ponieważ to uznane i realizowane normy określają wzór funkcjonujący w grupie. Autor definiuje te kategorie jako „zespół norm określających te właściwości, które winien wykazać i te zachowania, które winien realizować, każdy osobnik należący do danej 
w trakcie etapu badań terenowych prowadzonych w ramach przygotowania pracy magisterskiej. Badanymi byli przedstawiciele grup społeczno-zawodowych sektora miejskiej kultury oraz gier wideo i aplikacji mobilnych. Wykazano (a przynajmniej dążono do wskazania) występowanie dwóch krystalizujących się typów wzorów konsumpcji - „intelektualnego” oraz „praktycznego”. Pierwszy typ w głównej mierze reprezentują badani wrocławskiego sektora produkcji gier wideo i aplikacji mobilnych, drugi zaś pracownicy produkujący miejskie festiwale kulturalne. Podjęty temat jest istotny badawczo, ponieważ stosunkowo mało jest literatury poświęconej badaniu systemu wartości oraz sposobu konsumpcji oferty miejskiej przez przedstawicieli grup zawodowych sektora kreatywnego. Co więcej, artykuł podejmuje analizę relacji — na gruncie studiów miejskich wiążącej wzory konsumpcji ze strukturalnym ${ }^{3}$ usytuowaniem badanych. Rama teoretyczna opracowania obejmuje analizę $\mathrm{w}$ duchu teorii wartości postmaterialistycznych Ronalda Ingleharta ${ }^{4}$ oraz wartości kulturowych Floriana Znanieckiego i Williama Thomasa ${ }^{5}$, natomiast aspekt metodologiczny materiału badawczego został opracowany dzięki inspiracji pierwotną wersją metodologii teorii ugruntowanej ${ }^{6}$.

Aby przejść do postawionego celu — zbadania relacji (systemu) wartości ze strukturalnym usytuowaniem badanych oraz przejawianymi przez nich wzorami konsumpcji — należy skonceptualizować pierwsze pojęcie w wymiarze socjologicznym.

\section{Wokół pojęcia wartości oraz systemu aksjologicznego - krótkie wprowadzenie w perspektywie nauk społecznych}

Wartość w ujęciu socjologicznym jest pojęciem wieloznacznym, nieprecyzyjnym oraz ryzykownym w wymiarze operacjonalizacji na potrzeby badań empirycznych. Może ona być narzędziem analitycznym zarówno jednostek, grup społecznych, jak i całych społeczeństw oraz kultur, co jest kolejnym poważnym problemem metodologicznym. Jednak na potrzeby prowadzonej analizy podejmę

grupy" (ibidem, s. 381). Zatem to normy obowiązujące w grupie definiują treść wzoru społecznego powszechnie podzielanego przez jej członków.

${ }^{3} \mathrm{~W}$ niniejszym opracowaniu terminem „strukturalne usytuowanie” określam makrostrukturalne właściwości i specyfikę badanych przeze mnie grup. Drugim wymiarem analizy jest ich funkcjonowanie w wymiarze mezostrukturalnym, to jest relacji społecznych badanych grup w stosunku do przestrzeni miejskiej. Ostatnim kątem, pod którym badam przedstawicieli grup, są mikrostruktury, czyli przede wszystkim relacje społeczne z innymi grupami. Strukturalne usytuowanie zostało szerzej opisane w dalszej części artykułu.

${ }^{4}$ R. Inglehart, Pojawienie się wartości postmaterialistycznych, przeł. S. Czarnik, [w:] Socjologia. Lektury, red. P. Sztompka, M. Kucia, Kraków 2006.

5 F. Znaniecki, W. Thomas, Chłop polski w Europie i Ameryce, Warszawa 1976.

6 B. Glaser, A. Strauss, Odkrywanie teorii ugruntowanej, Kraków 2009. 
się wyzwania takiej konceptualizacji pojęcia wartości, aby odpowiadało ono specyfice badanych przeze mnie grup społeczno-zawodowych.

Maria Misztal definiuje pojęcie wartości w trzech płaszczyznach: psychologicznej, kulturowej oraz socjologicznej. Ostatni wymiar ugruntowany jest w tym, co społeczne - w położeniu strukturalnym, przynależności klasowej i zawodowej, w wypełnianiu ról społecznych itp. Autorka zauważa, że niemożliwe jest jednoznaczne odróżnienie jednego typu wartości od drugiego, ponieważ — jak powszechnie wiadomo - zakres pojęciowy wartości kulturowych obejmuje również zakres wartości psychologicznych i socjologicznych. Nie można zaprzeczyć, że wartości kulturowe (symboliczne) determinują uznawanie i odczuwanie wartości subiektywnych oraz społecznych (grupowych) przez członków grup społecznych. Co więcej, stosunkowo trudno odróżnić wartości społeczne od kulturowych, zważywszy, że te ostatnie są internalizowane (między innymi w procesie socjalizacji) przez aktorów społecznych uczestniczących w danej kulturze (a ona sama nie istnieje i istnieć nie może w odosobnieniu od społeczeństwa) ${ }^{7}$. Z kulturowego zabarwienia pojęcia wartości wychodzą Florian Znaniecki i William Thomas. To właśnie tworzenie sztuki i rozrywki jest wartością, którą pragną osiągać producenci festiwali kulturalnych i gier wideo ${ }^{8}$.

System wartości, orientacje aksjologiczne, świat wartości lub hierarchie wartości są określeniami mającymi na celu zbadanie oraz analizę tego samego pojęcia - relacji pomiędzy społecznie pożądanymi wartościami oraz wyłaniającą się w wyniku ludzkiego działania strukturą. Milton Rokeach jest zdania, że system wartości jest pewnym kontinuum porządkującym wartości, idee, przedmioty, dobra w sposób gradacyjny - na jednym krańcu znajdują się wartości najważniejsze, natomiast na drugim biegunie są wartości najmniej ważne z punktu widzenia danej grupy społecznej. Jadwiga Koralewicz-Zębik uważa, że to od badacza zależy, jak zrekonstruuje, w drodze analizy, relację i strukturę wartości danej grupy społecznej, zawodowej, na co położy nacisk i co pominie oraz z jakich powodów postąpi tak a nie inaczej ${ }^{9}$. Jest to niewątpliwie trudne zadanie.

W odniesieniu do prowadzonej analizy ważnym wymiarem orientacji aksjologicznych współczesnych społeczeństw jest teoria zmiany wartości autorstwa Ronalda Ingleharta. Twierdzi on, że we współczesnych społeczeństwach, między innymi pod wpływem rozwoju społeczno-ekonomicznego, dochodzi do przejścia od wartości materialistycznych do postmaterialistycznych. Tymi pierwszymi są na przykład pieniądze, rozwój gospodarczy społeczeństwa, bezpieczeństwo socjalne. Do tych drugich aktorzy społeczni dążą między innymi po zdobyciu wartości (oraz zaspokojeniu potrzeb) materialnych, chodzi o samorealizację, ochronę środowiska oraz praw zwierząt, poparcie mniejszości seksualnych, religijnych,

\footnotetext{
7 M. Misztal, Problematyka wartości w socjologii, Warszawa 1980, s. 13-18.

8 F. Znaniecki, W. Thomas, op. cit. s. 54-61.

9 J. Koralewicz-Zębik, System wartości a struktura społeczna, Wrocław 1974, s. 47-48.
} 
etnicznych itd. Aby dobrze zrozumieć tę koncepcję, należy sięgnąć do klasycznej już teorii potrzeb Abrahama Maslowa - w skrócie: podstawowymi potrzebami człowieka są te natury biologicznej, następnie te dotyczące bezpieczeństwa, przynależności, uznania, natomiast najważniejszymi są odnoszące się do szeroko pojętej samorealizacji ${ }^{10}$.

Teoria potrzeb Maslowa stanowi komplementarne i istotne uzupełnienie w wymiarze psychologicznego tła koncepcji - postulowanej przez Ingleharta - zmiany preferowanych wartości z materialistycznych na postmaterialistyczne ze względu na relacje łączące $\mathrm{z}$ jednej strony przemiany społeczne (modernizację) w sferze gospodarki (a w zasadzie jej rozwoju w wyniku rosnącej dynamiki procesów industrializacji i urbanizacji), kultury (istotności kultury popularnej i oddziaływania mass mediów na społeczeństwo) i polityki (wzrostu znaczenia wartości demokratycznych), z drugiej zaś przeobrażenia tożsamości (indywidualizacji wartości i norm, różnorodności światopoglądowej, różnych aspektów jakości życia) i osobowości (nacisk na samospełnienie, autoekspresję) człowieka nowoczesności ${ }^{11}$.

W kolejnej części artykułu chciałbym skupić się na kwestiach metodologicznych przeprowadzonych przeze mnie badań.

\section{Aspekt metodologiczny badania}

W badaniach posłużyłem się procedurami badawczymi i narzędziami analitycznymi wykorzystanymi w metodologii teorii ugruntowanej autorstwa Barneya Glasera i Anselma Straussa. Polega ona na budowaniu teorii średniego zasięgu ${ }^{12}$ na podstawie systematycznie zbieranych danych. Postaram się stworzyć teorię świata wartości badanych grup społecznych. Atutem metodologii jest łatwość w zoperacjonalizowaniu badanych pojęć (wartości), gdyż pochodzą one z bezpośredniej obserwacji empirycznej ${ }^{13}$.

Techniką badawczą, której użyłem w trakcie pracy terenowej, był wywiad epizodyczny. W trakcie wywiadu wywoływana jest krótka narracja mająca cechy procesu poznawczego oraz skłaniająca rozmówcę do tworzenia tymczasowych epizodów, w które uwikłane są codzienne działania skierowane na osiąganie

10 R. Inglehart, op. cit., s. 334-348.

11 A. Giddens, Nowoczesność i tożsamość. „Ja” i społeczeństwo w epoce późnej nowoczesności, Warszawa 2001.

12 W wypadku autorskich badań dążyłem do stworzenia teorii doświadczania wielkomiejskiej metropolii - Wrocławia.

13 K. Konecki, Studia z metodologii badań jakościowych. Teoria ugruntowana, Warszawa 2000, s. $25-30$. 
najcenniejszych i mniej ważnych wartości społecznych. Dzięki takim zabiegom mam zamiar częściowo zrekonstruować orientacje aksjologiczne badanych ${ }^{14}$.

Ogółem przeprowadzonych zostało dziewięć wywiadów z rozmówcami i rozmówczyniami w różnych kategoriach wiekowych - pięcioma $\mathrm{z}$ wrocławskiego sektora Video Game Developing oraz czterema z sektora produkcji festiwali kulturalnych. W badaniu wzięły udział cztery kobiety oraz pięciu mężczyzn, przy czym większość wywiadów w pierwszym sektorze przeprowadzona została z mężczyznami, natomiast całkowicie odwrotna sytuacja dotyczyła wywiadów z pracownikami kultury - przeprowadziłem wywiad z trzema rozmówczyniami oraz jednym rozmówcą. Badani z wrocławskiego sektora Video Game Developing pracowali ${ }^{15}$ łącznie w czterech firmach (dwóch produkujących aplikacje mobilne, jednej tworzącej gry akcji i jednej pracującej nad grą przeglądarkową). Liczba oraz rodzaj festiwalów kulturalnych produkowanych przez badanych różnił się w zależności od rozmówcy.

W kolejnej części przybliżę pokrótce autorską typologię „krystalizujących” się w badaniu, moim zdaniem, społecznych wzorów konsumpcji oferty miejskiej.

\section{Szkic typologii wzorów konsumpcji wrocławskiej oferty miejskiej przez badanych}

„Praktyczny” wzór konsumpcji oferty miejskiej skupia się wokół kwestii związanych z wartościami materialnymi. Badani akcentują aspekty związane z infrastrukturą miasta - działaniem komunikacji zbiorowej, cenami wynajmu mieszkań lub cenami samych nieruchomości dostępnych na terenie miasta. W swoich wypowiedziach rozmówcy kładą nacisk na istotność wydajnego funkcjonowania MPK (nie spełnia oczekiwań badanych oraz wymaga licznych usprawnień i modernizacji) i niskie ceny wynajmowanych mieszkań, które są — zdaniem rozmówców - relatywnie wysokie w mieście.

Drugim typem społecznego wzoru konsumpcji oferty miasta jest wymiar „intelektualny”. Pracownicy sektora produkcji festiwali, z racji wyższego poziomu kapitału kulturowego ${ }^{16}$ nabytego w trakcie wieloletniego procesu edukacji, mają odmienne orientacje aksjologiczne od pracowników Game Developing, którzy

14 U. Flick, The episodic interview. Small scale narratives as approach to relevant experiences, [w:] Discussion Papers - Qualitivate Series, red. M. Bauer, London 1997, s. 1-23.

${ }^{15}$ Praca magisterska dotyczyła tematyki doświadczenia zamieszkiwania oraz pracy we Wrocławiu, dlatego uważam, że aby dobrze zrozumieć rekonstrukcję systemu wartości, wzorów konsumpcji i usytuowania strukturalnego obydwu grup, trzeba zaznaczyć, w jakim sektorze pracują.

16 Pojęcie to jest przeze mnie rozumiane za P. Bourdieu i L. Wacquantem (Zaproszenie do socjologii refleksyjnej, przeł. A. Sawisz Warszawa 2001). Kapitałem kulturowym określam przede wszystkim wiedzę, idee i przedmioty o wartości kulturowej oraz kompetencje kulturowe i językowe nabyte przez człowieka podczas życia społecznego. Używając pojęcia kapitału kulturowego, mam na myśli bardziej jego zinstytucjonalizowaną formę - wykształcenie formalne, praktyczną (jak też zdobytą 
wyróżniają się technicznym wykształceniem. Dla tych pierwszych najważniejszą wartością jest między innymi bogata oferta kulturalna, która ma za zadanie nie tylko zaspokajać ich własne potrzeby, lecz także, a może przede wszystkim, potrzeby reszty mieszkańców miasta, ponieważ to dla nich produkowane są festiwale kulturalne. $\mathrm{Z}$ drugiej strony ich system wartości wiąże się ze swego rodzaju dystynkcją intelektualną pomiędzy producentami wydarzeń a resztą mieszkańców Wrocławia. Ci pierwsi wypełniają rolę społeczno-zawodową, której wartością autoteliczną jest „uświadamianie” mieszkańców poprzez tworzenie dla nich szeroko pojętej kultury. Zarówno kultura niska, jak i wysoka zaspokajają potrzeby mieszkańców. Poza tym dla pracowników sektora festiwali duże znaczenie mają oddolne programy animujące kulturę, działające fundacje oraz stowarzyszenia, które powinny być wspierane przez samych mieszkańców. Niebagatelny wpływ na miejską kulturę mają również programy odgórne organizowane przez władze miejskie oraz programy społeczne aktywizujące obywateli poszczególnych miejskich osiedli. Są one organizowane między innymi przez przedstawicieli sektora miejskiej kultury.

Ostatnim analizowanym $\mathrm{w}$ artykule wzorem konsumpcji charakteryzują się graficy 3D z sektora Game Devu. Specyfika owego wzoru łączy właściwości typu "praktycznego" i „intelektualnego". Z całą pewnością owa grupa ma wysoki poziom kapitału kulturowego wynikającego ze zdobytego wykształcenia artystycznego (ukończone studia w akademiach artystycznych) i technicznego. Są oni aktywni w siatce społecznej znajomych i kolegów dysponujących podobnym zasobem kapitału kulturowego oraz partycypujących w tych samych wydarzeniach kultury wysokiej organizowanej odgórnie i oddolnie ${ }^{17}$. Z drugiej strony łączą oni wzór „praktyczny”, w którym akcentowane są bardziej wartości ekonomiczne, takie jak niskie ceny wynajmu mieszkań oraz niskooprocentowane kredyty mieszkaniowe. Innymi przykładami są wartości związane z jakością życia w mieście - walory estetyczne i wysoki standard usług komunikacji miejskiej.

Przedstawione wzory mogą nam poniekąd powiedzieć o wartościach społecznych, którymi kierują się badani. W dalszej części artykułu chciałbym rozszerzyć analizę oraz dodać wymiar strukturalny w tworzeniu się systemu aksjologicznego badanych.

\footnotetext{
za pomocą zasobów sieci społecznych, w których uczestniczą badani) wiedzę z zakresu dziedzin reprezentowanych przez badanych.

17 Przez pojęcie kultury animowanej odgórnie mam na myśli wydarzenia kulturalne organizowane przez instytucje działające w magistracie miasta, na przykład biuro festiwalowe „Impart” czy program „MIKROGranty”. Kultura animowana oddolnie to z kolei wszystkie wydarzenia powstające spontanicznie dzięki działaniom podmiotów z sektora NGO lub każdego mieszkańca miasta, na przykład różnego rodzaju happeningi, performance’y itp. Są to, przykładowo, branżowe, o czym mówili badani w trakcie wywiadów.
} 


\section{Wzory konsumpcji i orientacje aksjologiczne a usytuowanie strukturalne rozmówców — ujęcie empiryczne}

Konsumpcja miejskiej oferty kulturalnej jest zdeterminowana umiejscowieniem przedstawicieli badanych sektorów w strukturze społecznej. Z jednej strony wartości badanych są akcentowane w zależności od społeczno-ekonomicznej specyfiki sektora, w którym pracują. Deweloperzy gier komputerowych (chodzi tutaj przede wszystkim o level designerów oraz game designerów ${ }^{18}$ ) uczestniczą częściej w wydarzeniach kulturalnych poświęconych na przykład muzyce z gier komputerowych lub kupują urządzenia związane $\mathrm{z}$ technologią 3D. Rzadziej uczestniczą w instytucjonalnej ofercie kulturalnej miasta — najczęściej są to festiwale muzyki rozrywkowej. $Z$ drugiej strony graficy 3D są usytuowani na „pograniczu kulturowym" wrocławskiego sektora kreatywnego. Wraz z producentami festiwali kulturalnych partycypują we wrocławskich wydarzeniach inicjowanych zarówno oddolnie, czasem także spontanicznie przez samych animatorów kultury, jak i odgórnie przez władze miejskie. Konsumpcja oferty kulturalnej nie jest aż tak atrakcyjna w doświadczeniach badanych pracowników sektora Game Developing. Praktyki konsumpcyjne ilustruje najlepiej wypowiedź jednego z rozmówców.

Piotr (Sektor Game Developing): Nie wiem czy można zakwalifikować Pyrkon pod takie coś [festiwale kulturalne - S.P.], PGA [targi gier komputerowych w Katowicach - S.P.] ewentualnie, ale tutaj, we Wrocławiu, nic, w sumie nic, bo nic takiego specjalnie nie było realizowane. Raz się zdarzyło Best Wrocław, to były takie jednodniowe, gdzie było mnóstwo gier planszowych, o, to na takim czymś byłem.

Badani z sektora produkcji gier i aplikacji kierują się wartościami skierowanymi na niewygórowaną rozrywkę, niewymagającą ,,intelektualnego wysiłku”.

Odmiennie wartości w ofercie kulturalnej pragną tworzyć i osiągać przedstawiciele sektora produkcji miejskich festiwali, ich praktyki uczestnictwa różnią się od tych prezentowanych przez producentów gier. Oferta kulturalna w doświadczeniach ludzi ją tworzących zawiera znaczną liczbę interesujących wydarzeń. Ma ona wystarczające możliwości zaspokojenia potrzeb kulturalnych mieszkańców miasta. Istnieje wiele miejsc animacji kultury oddolnej oraz odgórnej, gdzie każdy prędzej czy później odnajdzie wydarzenia kulturalne pasujące do własnego gustu. Również oferta lokalnych festiwali jest wystarczająco zróżnicowana, by doskonale zaspokajać wymagania mieszkańców miasta. Fundacje i stowarzyszenia to najczęściej podmioty animacji kultury oddolnej, odpowiadające na popyt ze strony

${ }^{18}$ Są to nazwy stanowisk w firmach produkujących gry komputerowe i aplikacje mobilne. Level designer zajmuje się projektowaniem wybieralnych stopni trudności danej gry lub aplikacji. Do obowiązków game designera należy — w skrócie - tworzenie zamysłu gry, fabuły, postaci, całego uniwersum itp. 
osób zamieszkujących Wrocław. O zaspokajaniu potrzeb kulturalnych mieszkańców najpełniej wypowiada się jedyny rozmówca z sektora kultury.

Marcin (Sektor Produkcji Festiwali): [...] nie miałem jeszcze sytuacji, że jakby powiedzieć, za przeproszeniem, cholera, wtedy nic się nie dzieje (śmiech), ale to też by było wtedy zaskoczeniem, bo w zasadzie jak to (śmiech), a nie, że czekałem parę tygodni, żeby w końcu coś. Ja rozumiem, że ktoś może mieć tak wyszukany gust, że trzeba będzie dłużej czekać, ale w końcu to się zdarzy, w końcu będzie wydarzenie, które pasuje, także z oferty kulturalnej jestem zadowolony.

W wypowiedzi Marcina wartością autoteliczną jest sama organizacja i uczestnictwo w festiwalu kulturalnym - zarówno przez organizatorów, jak i przez mieszkańców miasta.

Podsumowując, należałoby zadać pytanie, dlaczego wzory konsumpcji w ofercie miejskiej przedstawicieli obydwu sektorów się różnią? Dlaczego też eksponowane w wypowiedziach wartości dotyczące kultury i uczestnictwa w niej są aż tak odmienne? Aby to wyjaśnić, pozwolę sobie się odwołać do czynników makrostrukturalnych, które w pewnym stopniu objaśniają relacje partycypacji w miejskiej ofercie konsumpcyjnej i wartości obieranych przez badanych. Za sprawą specyfiki posiadanych zasobów producenci kultury uczestniczą w konsumpcji oferty miasta w sposób odmienny od przedstawicieli sektora Game Devu. Z całą pewnością mają większą ilość i jakość kapitału kulturowego (nabytego w trakcie wieloletniego procesu edukacyjnego i uzyskanego poza zinstytucjonalizowaną edukacją, czyli w trakcie uczestnictwa w sieci społecznej, w której biorą udział również ich znajomi o podobnych właściwościach kapitału, gustach kulturalnych, stylach życia itp.), który pozwala im przyswajać o wiele szerszy wachlarz wydarzeń kulturalnych niż tylko festiwale - na przykład muzyki rozrywkowej. Badani $\mathrm{z}$ sektora produkcji gier wideo $\mathrm{w}$ pewnym stopniu odznaczają się nieuczestniczeniem w wydarzeniach kultury wysokiej, zinstytucjonalizowanej, animowanej najczęściej oddolnie. Jest to związane w pewnym stopniu z „technicznym” wymiarem kapitału kulturowego, lecz z drugiej strony bardzo aktywnie uczestniczą w subkulturze poświęconej grom komputerowym.

„Intelektualny” wzór uczestnictwa w konsumpcji w wymiarze kulturowym odbywa się na płaszczyźnie dystansowania się badanych od reszty mieszkańców Wrocławia oraz tworzenia dystynkcji kultury na masową i/lub niską oraz kulturę wysoką. Wartości, którymi kierują się badani z sektora produkcji festiwali, są w relacji z „,intelektualnym” wzorem konsumpcji. Najlepiej zobrazowała je Barbara, rozmówczyni z sektora produkcji festiwali kulturalnych.

Barbara (SPF): [...] ja edukuję się w tej dziedzinie od dziecka i mam za sobą cały proces edukacyjny poza powszechnym jeszcze artystycznym, wobec czego też wchodzę w te sytuacje trochę odmiennie, i dostrzegam je odmiennie, i mam z nimi do czynienia w trochę odmienny sposób, więc gdybym była takim człowiekiem cywilnym, co by wtedy było dla mnie takie znaczące.... Nie wiem, wydaje mi się [...], że te momenty, które były takimi dużymi formami, czyli np. to, co się, co wyszło poza obiekt i wydarzyło się w terenie, i w przestrzeni, i było takie dla mas, takie masowe, to wydaje mi się, że to zrobiło dla mnie wrażenie, aczkolwiek ja w tej masówce nigdy nie uczestniczyłam. 
Pracownicy sektora produkcji miejskich festiwali mają określony etos zawodowy, związany z misją tworzenia kultury oraz jej przekazywania reszcie mieszkańców miasta (ludzi „cywilnych”). Można powiedzieć, że przedstawiciele sektora produkcji festiwali czują się swego rodzaju miejską „elitą intelektualną", dystansującą się od wydarzeń „masowych”, ale jednocześnie produkującą je, ponieważ jest to związane $\mathrm{z}$ etosem, czyli „misją tworzenia” kultury. W doświadczeniach badanych można zaobserwować spore znaczenie wykształcenia artystycznego, które odgrywa zasadniczą rolę w wymiarze tworzenia świata wartości badanych z sektora kultury.

Makrostrukturalnym czynnikiem warunkującym obieranie określonej orientacji aksjologicznej jest zasób kapitału kulturowego nabytego w wyniku formalnej i nieformalnej edukacji ${ }^{19}$. Jej wieloletni proces oraz rozwój doskonalenia własnych umiejętności przedstawia doświadczenie Mariusza - grafika 3D.

Mariusz (SGD): [...] uczyłem się. Po podstawówce zawsze, kurczę, dużo rysowałem, potem poszedłem do plastyka - 6 lat plastyka, potem właśnie 3 lata na ASP. Jeszcze rok byłem na filmówce w SKiBA, to ja cały czas po prostu cisnąłem w branży, cały czas rysowanie, grafika, cały czas, non stop ciężka praca, skillowanie.

Kolejnym wymiarem roli pasji w pracy jako wartości jest trudność w oddzieleniu życia prywatnego od zawodowego - „życie pracą”. Zdeterminowana jest to z całą pewnością zainteresowaniami oraz wykształceniem z zakresu humanistyki. Praca badanych z sektora produkcji festiwali kulturalnych wiąże się z wypełnianiem misji opierającej się na kulturowym uświadamianiu reszty mieszkańców Wrocławia. Polega ona na tworzeniu festiwali, podczas których obywatele miasta mogą obcować $\mathrm{z}$ kulturą. $\mathrm{Z}$ tego względu badani niestrudzenie wykonują swoje obowiązki, mimo że nie są one często dobrze płatne. Wymiar ten jest związany z wzorem „intelektualnym”, to jest z przekazywaniem wartości kulturowych reszcie mieszkańców. Najpełniej wymiar ten prezentuje wypowiedź Barbary:

Barbara (SPF): Cokolwiek bym nie robiła $\mathrm{w}$ tej materii, to mam tylko jedną ambicję, chcę, żeby to po prostu było, oddało [organizacja festiwali - S.P.] jak gdyby zamierzoną treść, do tego służy mi wysiłek, więc ja nie mam takich ambicji prywatnych, bo ja to uważam dalej za mój zawód i moją pracę.

Praca jako pasja w doświadczeniach pracowników sektora miejskiego Game Developing wykazuje podobne właściwości - nie można im odmówić zapału do niej, stanowi jedną z najważniejszych wartości. Jest to dynamiczny proces, ponieważ towarzyszy on badanym codziennie - chodzi tu o spotkania towarzyskie, podczas których wymieniane są pomysły oraz uwagi dotyczące technicznych aspektów produkcji, kontemplacja twórczości różnych malarzy, czerpanie wzajemnych inspiracji z własnej pracy czy konkurencja z kolegami, napędzająca rozwój własnych umiejętności. Pomimo częstego samowyzysku pracownicy

${ }^{19} \mathrm{O}$ doświadczeniach wieloletniego procesu edukacyjnego wypowiadała się także Barbara w cytacie powyżej. 
motywowani są innymi gratyfikacjami (wartościami), jak chociażby prestiżem społecznym zdobytych kompetencji i reputacją profesjonalisty w środowisku. Doświadczenia związane z pasją pracy w VDG ukazuje najlepiej wypowiedź Roberta.

Robert (SGD): [...] już wielokrotnie o tym mówiłem, ale jeżeli przebywasz z kimś przez 5 dni w tygodniu po 8 godzin, wiesz, że tym ludziom możesz zaufać, i wygląda to tak, że ci ludzie $\mathrm{z}$ najniższego szczebla naprawdę wkładają $\mathrm{w}$ to serce. Ja przez tyle lat, jak pracowałem - szczególnie na początkach kariery było tak, że ludzie siedzieli w pracy np. po 17 godzin, po kilkanaście godzin robili nadgodziny i nigdy np. nie liczyli na wynagrodzenie, i najczęściej tego wynagrodzenia nie było. Robili to po prostu z czystej pasji.

Reasumując, rola pasji w pracy kreatywnej w sektorze VDG oraz kultury ma takie samo podłoże - napędza proces twórczy. Również uczestnictwo w sieciach społecznych dynamizuje omawiane zjawisko - przede wszystkim społecznymi wzorami spędzania wolnego czasu i konsumpcji zarówno w jednym, jak i w drugim sektorze. Satysfakcja wynikająca z pracy jest pierwszą i prawdopodobnie najważniejszą wartością, którą otrzymują badani w trakcie wykonywania obowiązków.

Zawód kreatywny ${ }^{20}$ generuje dystans i bariery społeczne przejawiające się przede wszystkim społecznymi wzorami spędzania wolnego czasu, posiadanymi umiejętnościami i zdolnościami, z całą pewnością intelektualnymi, a nie fizycznymi. Samorealizacja w sektorze VGD przejawia się przede wszystkim dystynkcją pomiędzy pracą kreatywną a fizyczną. Wartością dodaną tej pierwszej jest również możliwość rozwoju własnego talentu oraz często tworzenie gier komputerowych przy jednoczesnej „zabawie” w miejscu zatrudnienia. W doświadczeniach pracowników ujawnia się także narracja „błogosławieństwa” pracy kreatywnej w Game Deve, albowiem jej atrakcyjnością oprócz zarobków jest również satysfakcja, pozorny brak większego stresu. Praca niekreatywna, najczęściej fizyczna, jest postrzegana w kategoriach braku możliwości rozwoju, stagnacji zawodowej i wyczerpania fizycznego. Wypowiedź Mariusza najlepiej oddaje wartości zawodu kreatywnego.

Mariusz (SGD): Nie no, mi się wydaje, że wszyscy sprawiają wrażenie spełnionych, zadowolonych właśnie, no chyba, że pracuje za 2 tysiące miesięcznie, to wtedy za to człowieka szlag trafia, jak się dowie, wiesz, koledzy z branży ile zarabiają. Wiesz, jak ja byłem na pierwszej rozmowie i pierwszą wypłatę wynegocjowałem 3 tysiące złotych [...]. Ale mi się wydaje, że są tacy zadowoleni, że to jest taka branża, jak nie wiem, praca na budowie, że kiedy też pracowałem na budowie, to człowiek po robocie jak zombi siedzi, nie ma o czym gadać po prostu, zmęczony, obolały, masz ochotę walnąć browara i położyć się spać. A u nas, w firmie, no to co, idziemy na gokarty jeszcze, chodzimy na siłkę czy coś takiego [...].

Samorealizacja $\mathrm{w}$ pracy przedstawicieli sektora produkcji festiwali kulturalnych wiąże się również z tak zwaną misją tworzenia kultury, o której pisałem

20 R. Florida, Narodziny klasy kreatywnej, przeł. T. Krzyżanowski, M. Penkala, Warszawa 2010, s. 83-84; K. Wojnar, Polska klasa kreatywna, Warszawa 2016, s. 56-59. 
wcześniej. Ostatecznie najważniejszym imperatywem, którym kierują się pracownicy, jest uświadamianie kulturalne mieszkańców, zaznajamianie ich z kulturą wysoką, nawet jeśli miałoby się to wiązać $\mathrm{z}$,przemycaniem” jej elementów do kultury masowej, jak czyni to Marcin, pracujący również w sektorze VGD. W pewnym sensie „trudność” (brak stabilności finansowej) wykonywania zawodu, o którym mówi Marcin, czyni tę pracę wartościową w oczach badanych, ponieważ nie każdy może podjąć się takiej „misji” (wykonywanej przez „wybrańców”) szerzenia kultury, a jest to wartość autoteliczna ze względu na swą doniosłość. Owo dążenie wydaje się wartością ważniejszą od gratyfikacji materialnych. O awangardowej „misji” własnego zawodu dobitnie wypowiada się Marcin.

Marcin (SPF): [...] także jak się czuje, że tworzę kulturę, no czuję się świetnie, że mam taką okazję, że możemy coś przekazać, że możemy albo sami od siebie pokazać coś ciekawego, twórczego, albo pouczającego, albo że jesteśmy w stanie skontaktować [się - S.P.] z ludźmi, z takimi osobami, które są w stanie to zrobić, także jest to bardzo uprzywilejowana pozycja i ja przynajmniej się cieszę z takiej możliwości, chociaż no zawsze to będzie taka praca pod górkę, ale właśnie o to chodzi, gdyby to było łatwe, to by to wszyscy robili.

Podsumowując, część badanych — zarówno z sektora VGD, jak i z sektora produkcji festiwali - myśli o podjęciu własnej działalności gospodarczej i/lub przebranżowieniu. O ile $\mathrm{w}$ przypadku drugiego sektora wynika to $\mathrm{z}$ uwarunkowań instytucjonalnych finansowania festiwali, o tyle $\mathrm{w}$ odniesieniu do pierwszego jest to uwarunkowane pragnieniem spełnienia własnych ambicji, rozwoju umiejętności, nowych możliwości lub większego zarobku. Samorealizacja w pracy ma natomiast różne wymiary na płaszczyźnie „praktycznej” i „intelektualnej”. Ten pierwszy wzór to przede wszystkim specyficzny styl życia oraz praktyka spędzania wolnego czasu - przede wszystkim poprzez wybieranie wydarzeń z miejskiej oferty kulturalnej, natomiast desygnatem tego drugiego z całą pewnością są wartości niematerialne - szerzenie świadomości kulturalnej, zaznajamianie mieszkańców miasta z kulturą, nauką partycypacji w niej.

\section{Podsumowanie}

Relacja łącząca strukturalne usytuowanie, system wartości oraz wzory konsumpcji przedstawicieli zawodów kreatywnych jest zniuansowana. Oprócz dwóch podstawowych typów krystalizuje się istnienie rodzaju łączącego w sobie elementy poprzednich. To w głównej mierze pozycja społeczna, klasa, wykonywany zawód i wykształcenie determinują obieranie takich, a nie innych wartości przez badanych. Te ostatnie natomiast decydują o wzorach konsumpcji, które przejawiają badane osoby. Głównym czynnikiem jest przede wszystkim wykształcenie rozmówców oraz ich zasób kapitału kulturowego. Przedstawiciele sektora VGD charakteryzują się "praktycznym” wzorem konsumpcji związanym z technicznym wykształceniem (umiejętności manualne, zdolności analitycznego myślenia) oraz 
odpowiednim aspektem kapitału, który wynika z technicznego wykształcenia. Badani z sektora kultury natomiast prezentują „intelektualny” sposób konsumpcji, ponieważ charakter ich kapitału jest bardziej „humanistyczny” z racji zdobytego wykształcenia. Rozmówcy branży kreatywnej charakteryzują się również odrębnym stylem życia, społecznymi wzorami spędzania czasu wolnego, podobnymi do tych charakteryzujących przedstawicieli nowej klasy średniej w sensie neomarksistowskim ${ }^{21}$.

Moim celem nie było całościowe zrekonstruowanie systemu aksjologicznego badanych przedstawicieli grup społeczno-zawodowych - jest to zadanie niewykonalne przy tak małej ilości danych. Nie jest też możliwe wskazanie wszystkich wartości, którymi kierują się badani, dlatego skupiłem się na wartościach kulturowych (w ujęciu teorematu F. Znanieckiego i W. Thomasa), postmaterialistycznych i materialistycznych, analizując je w kontekście teorii R. Ingleharta. Sama próba badawcza nie ma znamion reprezentatywności ze względu na liczbę badanych, niemniej spełnia ona kryteria teoretycznego doboru próby ${ }^{22}$. Wyniki badań rodzą także kolejne pytania i otwierają nowe pola do dyskusji. W ramach triangulacji metodologicznej warto przeprowadzić dodatkowo wśród przedstawicieli badanych grup komplementarne badania ilościowe wykorzystujące skonstruowane kategorie badawcze, co może pogłębić analizę o kolejne wymiary (strukturalne i kulturowe) orientacji aksjologicznych przedstawicieli badanych grup.

\section{Bibliografia}

Babbie E., Podstawy badań społecznych, przeł. W. Betkiewicz, M. Bucholc, P. Gadomski, J. Haman,

A. Jasiewicz-Betkiewicz, A. Kloskowska-Dudzińska, M. Kowalski, M. Mozga, Warszawa 2008. Bourdieu P., Wacquant L., Zaproszenie do socjologii refleksyjnej, przeł. A. Sawisz, Warszawa 2001. Flick U., The episodic interview. Small scale narratives as approach to relevant experiences, [w:]

M. Bauer, Discussion Papers - Qualitivate Series, London 1997.

Florida R., Narodziny klasy kreatywnej, przeł. T. Krzyżanowski, M. Penkala, Warszawa 2010.

Giddens A., Nowoczesność i tożsamość. „Ja” i społeczeństwo w epoce późnej nowoczesności, przeł.

A. Szulżycka,_Warszawa 2001.

Glaser B., Strauss, A., Odkrywanie teorii ugruntowanej, przeł. M. Gorzko, Kraków 2009.

Inglehart R., Pojawienie się wartości postmaterialistycznych, przeł. S. Czarnik, [w:] Socjologia. Lektury, red. P. Sztompka, M. Kucia, Kraków 2006.

Koralewicz-Zębik J., System wartości a struktura społeczna, Wrocław 1974.

Konecki K., Studia z metodologii badań jakościowych. Teoria ugruntowana, Warszawa 2000.

Misztal M., Problematyka wartości w socjologii, Warszawa 1980.

Szczurkiewicz T., Studia socjologiczne, Warszawa 1970.

Turner J., Struktura teorii socjologicznej, red. A. Manterys, G. Woroniecka, Warszawa 2004.

Wojnar K., Polska klasa kreatywna, Warszawa 2016.

Znaniecki F., Thomas W., Chłop polski w Europie i Ameryce, Warszawa 1976.

${ }^{21}$ J. Turner, Struktura teorii socjologicznej, red. A. Manterys, G. Woroniecka, Warszawa 2004, s. $249-251$.

22 B. Glaser, A. Strauss, op. cit., s. 52-53; K. Konecki, op. cit., s. 30-31. 


\section{Social consumption patterns and the axiological system of Wroclaw's producers of culture and video games: The context of empirical research}

\section{Summary}

The discussion regarding the research on social values remains valid ever since the beginning of sociology as a science. Although the category itself has a flawed analytical nature, it is still regarded as one of the most effective tools in empirical research. The aim of the article is to focus on the relation binding together the structural placement of the workers employed in the culture and video game economy; the foundation of the worker's axiological system and the social consumption patterns followed by the producers. During the research, three social patterns have been discovered: the "intellectual" pattern manifested by the cultural workers, the "practical" one displayed by the game developers, and a mix of the aforementioned ones - demonstrated by the 3D graphics engineers. 